\title{
FREQUENCY OF ANEMIA IN PATIENTS WITH INCREASED LEVEL OF PARATHYROID HORMONE AMONG PATIENTS ON MAINTENANCE HEMODIALYSIS.
}

1. MBBS, FCPS Nephrology Consultant Nephrologist Armed Forces Hospital Southern Region, Saudia Arabia.

2. MBBS, MRCP (UK) (Internal Medicine), FCPS (Nephrology) Assistant Professor Nephrology Baqai Medical University

3. MBBS, FCPS Nephrology Consultant Nephrologist Armed Forces Hospital Southern Region, Saudia Arabia.

4. MBBS, Former PG trainee (Nephrology)

The Kidney Centre Postgraduate Training Institute.

5. MBBS, Former PG trainee (Nephrology)

Sindh Institute of Urology and Transplantation, Pakistan.

6. MBBS, FCPS (Nephrology) Consultant Nephrologist

Tabba Kidney Institute, Pakistan.

Correspondence Address:

Dr. Anita Haroon

Assistant Professor Nephrology

Baqai Medical University

dr.anitaharoon@gmail.com

Article received on:

21/10/2019

Accepted for publication:

$18 / 12 / 2019$
Saad Muzaffar Azeem', Anita Haroon², Ishtiaque Alam³, Sadia Azeem, Mahrukh Sultana ${ }^{5}$, Kulsoom Mansoor ${ }^{6}$

ABSTRACT... Objectives: One of the most frequently occurring complication of end stage renal disease is anemia. It can be defined as decrease in red blood cells with hemoglobin concentration less than $12 \mathrm{~g} / \mathrm{dl}$ in women and less than $13 \mathrm{~g} / \mathrm{dl}$ in men. Parathyroid hormone levels are also raised among patients with end stage renal disease to maintain serum calcium levels. The objective of this study is to evaluate the degree of anemia in patients with end stage renal disease currently on maintenance hemodialysis and have raised PTH levels. Study Design: Cross-sectional study. Setting: Kidney Center, Karachi. Period: November 2015 to July 2016. Material \& Method: Patients undergoing maintenance hemodialysis during the study duration with PTH levels greater than $300 \mathrm{ng} / \mathrm{L}$ were included in the study. Patients with other co-morbid conditions like chronic liver disease and hypersplenism were excluded from the study. Results: The total number of patients on maintenance hemodialysis in the kidney center that matched our inclusion criteria was 110. Amongst them there were $47.3 \%(n=52)$ males and $52.7 \%(n=58)$ females. The mean age of patients in our study is $50.15 \pm 12.92$ years. The mean PTH level of patients was found to be $642 \pm 405.9 \mathrm{U}$. Since all the participants of the study are on maintenance dialysis, the mean duration of hemodialysis was found to be $4.2 \pm 3.19$ months. The mean hemoglobin level of patients was found to be $9.75 \pm 1.47 \mathrm{~g} /$ dl. Conclusion: Patients with hyperparathyroidism and undergoing maintenance hemodialysis frequently develops anemia. Many factors account for this including raised PTH levels causing bone marrow fibrosis, decreased production of erythropoietin and resistance of produced erythropoietin are some factors responsible for the anemia.

Key words: $\quad$ Anaemia, Parathyroid Hormone, Maintenance Hemodialysis, Erythropoietin.

Article Citation: Azeem SM, Haroon A, Alam I, Azeem S, Sultana M, Manssor K. Frequency of anemia in patients with increased level of parathyroid hormone among patients on maintenance hemodialysis. Professional Med J 2020; 27(6):1255-1258. DOI: 10.29309/TPMJ/2020.27.06.4272

\section{INTRODUCTION}

One of the most common complication of end stage renal disease is anemia, primarily due to decreased erythropoietin production by the kidneys leading to decrease in red blood cell count. Anemia can be defined as decreased hemoglobin levels i.e less than $12 \mathrm{~g} / \mathrm{dl}$ in women and less than $13 \mathrm{~g} / \mathrm{dl}$ in men. ${ }^{1}$ There are multiple studies conducted to evaluate the severity and multiple mechanisms related to anemia. It has been recommended internationally to use supplements of iron, folate and synthetic erythropoietin to manage the associated anemia. ${ }^{2}$ The NHANES survey showed that the levels of hemoglobin decreases directly in proportion to the decrease in glomerular filtration rate (GFR).
It concluded that the prevalence of anemia in these patients can range anywhere from $1 \%$ to $67 \%$. The prevalence of anemia was reported to be $67 \%$ at GFR of $15 \mathrm{ml} / \mathrm{min}^{3}$ Anemia among these patients can further lead to altered cardiac output and cardiac complications. ${ }^{4}$ Another mechanism suggested by researchers is the role of the parathyroid hormone in anemia. ${ }^{5,6}$ Along with inflammation and iron deficiency, the raised parathyroid hormone level also contributes in causing anemia by causing bone marrow fibrosis. There are multiple mechanisms suggested by researchers by which raised PTH levels can further decrease hemoglobin and one of the most commonly suggested mechanism is bone marrow fibrosis. ${ }^{7,8}$ Researchers have 
proved their hypothesis by concluding that parathyroidectomy led to elevation in hemoglobin levels and decreased requirement for synthetic erythropoietin. $^{9}$

The objective of this study is to evaluate the frequency of anemia in patients with end stage renal disease undergoing maintenance hemodialysis and have raised PTH levels.

\section{MATERIAL \& METHODS}

This is a cross-sectional study performed at the Kidney Center, Karachi. The study duration was starting from November 2015 to July 2016. Patients undergoing maintenance hemodialysis for more than 3 months for end stage renal disease with PTH levels greater than $300 \mathrm{ng} /$ $\mathrm{ml}$ were included in the study. The age range of patients was 18 to 65 years. Patients with other co-morbid conditions such as chronic liver disease, hypersplenism, auto-immune diseases, gastrointestinal and genitourinary pathologies were excluded from study. Patients had PTH levels measured and CBC were performed. Data was analyzed using SPSS v.20. T-test and Chi square were used to analyze p-value and the association between hemoglobin and PTH levels among patients on maintenance hemodialysis were analyzed.

\section{RESULTS}

The total number of patients on maintenance hemodialysis in the kidney center that matched our inclusion criteria was 110. Amongst them there were $47.3 \%(n=52)$ males and $52.7 \%(n=58)$ females. The mean age of patients in our study was $50.15+12.92$ years. The mean PTH level of patients was found to be $642+405.9$ units. The mean duration of hemodialysis was found to be $4.2 \pm 3.19$ months. The mean hemoglobin level of patients was found to be $9.75 \pm 1.47 \mathrm{~g} / \mathrm{dl}$. The range of hemoglobin level was found between 8.5 to $11 \mathrm{~g} / \mathrm{dl}$. Table-l shows associated co-morbid of the patients in the study. Table-Il shows the correlation of anemia to different factors like age and co-morbid. Figure-1 shows the correlation of anemia to Hepatitis B\&C."

\begin{tabular}{|c|c|c|c|}
\hline Variable & \multicolumn{2}{|c|}{ No. of Patients } & Percentage \\
\hline Hepatitis B & \multicolumn{2}{|c|}{12} & $11 \%$ \\
\hline Hepatitis C & \multicolumn{2}{|c|}{18} & $16.3 \%$ \\
\hline Diabetes Mellit & \multicolumn{2}{|c|}{56} & $51 \%$ \\
\hline Hypertension & \multicolumn{2}{|c|}{108} & $98.2 \%$ \\
\hline \multicolumn{4}{|l|}{ Anemia } \\
\hline Yes & \multicolumn{2}{|c|}{85} & $77.27 \%$ \\
\hline NO & \multicolumn{2}{|c|}{25} & $22.72 \%$ \\
\hline \multicolumn{4}{|c|}{ Table-I } \\
\hline \multirow{2}{*}{ Variable } & \multicolumn{2}{|c|}{ Anemia } & \multirow{2}{*}{ P-Value } \\
\hline & Yes & No & \\
\hline \multicolumn{4}{|l|}{ Age } \\
\hline 20-45 years & 27 & 12 & \multirow{2}{*}{0.296} \\
\hline $46-70$ years & 42 & 26 & \\
\hline \multicolumn{4}{|l|}{ Gender } \\
\hline Male & 29 & 23 & \multirow{2}{*}{0.153} \\
\hline Female & 40 & 18 & \\
\hline \multicolumn{4}{|c|}{ Duration of Hemodialysis } \\
\hline $0.5-8$ years & 72 & 21 & \multirow{2}{*}{$<0.001$} \\
\hline $9-16$ years & 13 & 4 & \\
\hline
\end{tabular}

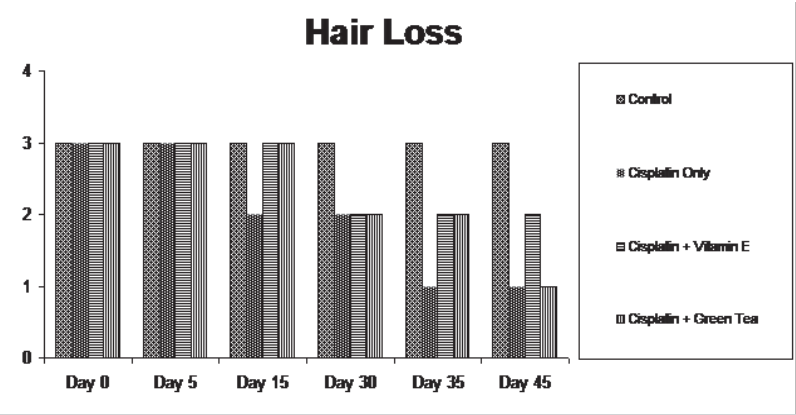

Figure-1

\section{DISCUSSION}

Subjects in our study had anemia and raised PTH levels. The mean hemoglobin level in our study was $9.75 \pm 1.47 \mathrm{~g} / \mathrm{dl}$ which is less than normal. It can be concluded that raised $\mathrm{PTH}$ levels inhibit the production of red blood cells and alleviate the degree of anemia. Other studies have also concluded this finding..$^{10}$ Bone marrow fibrosis decreased production of erythropoietin and resistance of produced erythropoietin are some factors responsible for the anemia. ${ }^{11}$ Patients with high levels of $\mathrm{PTH}$ require greater 
levels of synthetic erythropoietin. Yasunaga has concluded in his study that even after a year of parathyroidectomy the requirement for synthetic erythropoietin was not raised. ${ }^{12}$

Chutia and ruram conducted a study to evaluate the role of PTH levels and anemia among patients with end stage renal disease. His study results conclude that there is an inverse relation between serum PTH and hemoglobin levels. ${ }^{13}$ Baradran and Nasri have also concluded in their study that raised PTH levels can be correlated directly with the degree of anemia and inversely with hemoglobin levels. ${ }^{14}$ Trovato et al has also concluded the same findings and he has also suggested that the levels of recombinant erythropoietin should be increased among patients with raised levels of PTH. ${ }^{15}$

Zingraff et al performed parathyroidectomy and observed an increase in hemoglobin levels from $6 \mathrm{~g} / \mathrm{dl}$ to $9 \mathrm{~g} / \mathrm{dl}$ among 8 patients. This study proved significant association between hyperparathyroidism and anemia. This study was conducted in 1978 and it was the first study showing association between hyperparathyroidism and anemia. ${ }^{16}$ Goicoechea et al conducted a similar study and showed a significant improvement in anemia and decreased requirement for erythropoietin. He concluded that the erythropoietin requirements decreased from 194 to 94 units per $\mathrm{kg}$ body weight per week. ${ }^{17}$

Researchers have suggested that the raised PTH levels contribute to decreased osmotic fragility and hence account for decreased hemoglobin. ${ }^{18}$ Another mechanism suggested by researchers is the resistance of produced erythropoietin which hinders erythropoiesis. ${ }^{18,19}$

The limitation of our study includes small sample size and inability to evaluate the improvement in hemoglobin levels after the correction of hyperparathyroidism.

\section{CONCLUSION}

It can be concluded that patients with hyperparathyroidism undergoing maintenance hemodialysis frequently develops anemia. This could be due to decreased osmotic fragility and resistance of produced erythropoietin leading to increased breakdown and decreased production of red blood cells respectively that accounts for increase in the need of erythropoietin dose and also put extra financial burden to the patients. Further studies are required to investigate the underlying mechanism and its management.

Copyright 18 Dec, 2019.

\section{REFERENCES}

1. Guinn NR, Guercio JR, Hopkins TJ, Grimsley A, Kurian DJ, Jimenez MI, Bolognesi MP, Schroeder R, Aronson $S$, Duke Perioperative Enhancement Team (POET). How do we develop and implement a preoperative anemia clinic designed to improve perioperative outcomes and reduce cost?. Transfusion. 2016 Feb; 56(2):297-303.

2. Bellasi A, Mangano S, Minoretti C, Campana C, Di lorio B, Di Lullo L, Ratti C, Cozzolino M. Single-center openlabel randomized study of anemia management improvement in ESRD patients with secondary hyperparathyroidism. Nephrology@ Point of Care. 2016; 2(1):pocj-5000196.

3. Astor BC, Muntner P, Levin A, et al. Association of kidney function with anemia: the Third National Health and Nutrition Examination Survey (19881994). Arch Intern Med. 2002; 162:1401.

4. KDIGO clinical practice guidelines for anemia in chronic kidney disease. Kidney Int Suppl. 2012;2:288

5. Yohay DA, Quarles LD. Clinical applications of parathyroid hormone immunoassays in patients with end stage renal disease. In Seminars in Dialysis 1993 Sep (Vol. 6, No. 5, pp. 305-311). Oxford, UK: Blackwell Publishing Ltd.

6. Block GA. The impact of calcimimetics on mineral metabolism and secondary hyperparathyroidism in end-stage renal disease: Management of comorbidities in kidney disease in the 21st century: Anemia and bone disease. Kidney international. 2003 Nov 1; 64:S131-6.

7. Fishbane $S$, Berns JS. Hemoglobin cycling in hemodialysis patients treated with recombinant human erythropoietin. Kidney international. 2005 Sep $1 ; 68(3): 1337-43$. 
8. Grützmacher P, Radtke HW, Fassbinder W, Koch KM, SchoeppeW. Effect of secondary hyperparathyroidism on the anaemia of end-stage renal failure: In vivo and in vitro studies. Proceedings of the European Dialysis and Transplant Association. European Dialysis and Transplant Association. 1983; 20:739-45.

9. Bhadada SK, Bhansali A, Shah VN, Behera A, RavikiranM, Santosh R 2011 High prevalence of cholelithiasis in primary hyperparathyroidism: Retrospective analysis of 120 cases. Indian J Gastroenterol 30:100 -101 .

10. Rao DSShih MSMohini R Effect of serum parathyroid hormone and bone marrow fibrosis on the response to erythropoietin in uremia. N Engl J Med1993; 328 (3) 171- 175

11. Mandolfo SMalberti Farina MVilla GScanziani RImbasciati E Parathyroidectomy and response to erythropoietin therapy in anaemic patients with chronic renal failure. Nephrol Dial Transplant 1998; 13 (10) 2708- 2709.

12. Yasunaga CMatsuo KYanagida TMatsuo SNakamoto MGoya $T$ Early effects of parathyroidectomy on erythropoietin production in secondary hyperparathyroidism. Am J Surg 2002; 183 (2) 199- 204.

13. Chutia $H$, Ruram AA, Bhattacharyya $H$, Boruah $P$, Nath C. Association of secondary hyperparathyroidism with hemoglobin level in patients with chronic kidney disease, J Lab Physicians 2013; 5(1): 51-4.
14. Baradaran $A$, Nasri $H$. Intensification of anaemia by secondary hyperparathyroidism in hemodialysis patients, Med J Islam Acad Sci 2001; 14(4): 161-6.

15. Trovato GM, Carpinteri G, Spina S, Squatrito G, Catalano D, lannetti E. Hyperparathyroidism, anaemia and erythropoietin: Effects on systolic function of dialysis patients. Abstracts of 31st Congress of European Renal Association/European Dialysis and Transplantation Association, September 5-8, 1999. Madrid in Nephrol Dial Transpl. 1999; 14:190.

16. Zingraff J, Drueke T, Marie P, Man NK, Jungers P, Bordier P. Anemia and secondary hyperparathyroidism. Arch Intern Med 1978; 138: 1650-2.

17. Goicoechea M, Gomez-Campdera F, Polo JR, Tejedor A, Ruiz MA, Vazquez MI, et al. Secondary hyperparathyroidism as cause of resistance to treatment with erythropoietin: Effect of parathyroidectomy. Clin Nephrol 1996; 45: 420-1.

18. Wu SG, Jeng FR, Wei SY, Su CZ, Chung TC, Chang WJ, et al. Red blood cell osmotic fragility in chronically hemodialyzed patients. Nephron 1998; 78: 28-32.

19. Sikole A: Pathogenesis of anemia in hyperparathyroidism. Med hypotheses 2000; 54(2): 236-8.

20. Cunningham J, Locatelli F, Rodriguez M. Secondary hyperparathyroidism: Pathogenesis, disease progression and therapeutic options. Clin J Am Soc Nephrol 2011; 6: 913-21.

\begin{tabular}{|c|c|c|c|}
\hline \multicolumn{4}{|c|}{ AUTHORSHIP AND CONTRIBUTION DECLARATION } \\
\hline Sr. \# & Author(s) Full Name & Contribution to the paper & Author(s) Signature \\
\hline 1 & $\begin{array}{l}\text { Saad Muzaffar Azeem } \\
\text { Anita Haroon }\end{array}$ & $\begin{array}{l}\text { All authors contributed equally. } \\
\text { To the conception or design } \\
\text { of the study, in analysis and } \\
\text { interpretation of data for the }\end{array}$ & \\
\hline 3 & Ishtiaque Alam & $\begin{array}{l}\text { work. } \\
\text { In drafting of the work and }\end{array}$ & \\
\hline 4 & Sadia Azeem & $\begin{array}{l}\text { revising it critically for important } \\
\text { intellectual content. }\end{array}$ & \\
\hline 5 & Mahrukh Sultana & All authors contributed in final & \\
\hline 6 & Kulsoom Mansoor & $\begin{array}{l}\text { published and agreed to be } \\
\text { accountable for all aspects } \\
\text { of the work in ensuring that } \\
\text { questions related to the } \\
\text { accuracy or integrity of any part } \\
\text { of the work are appropriately } \\
\text { investigated and resolved. }\end{array}$ & \\
\hline
\end{tabular}

